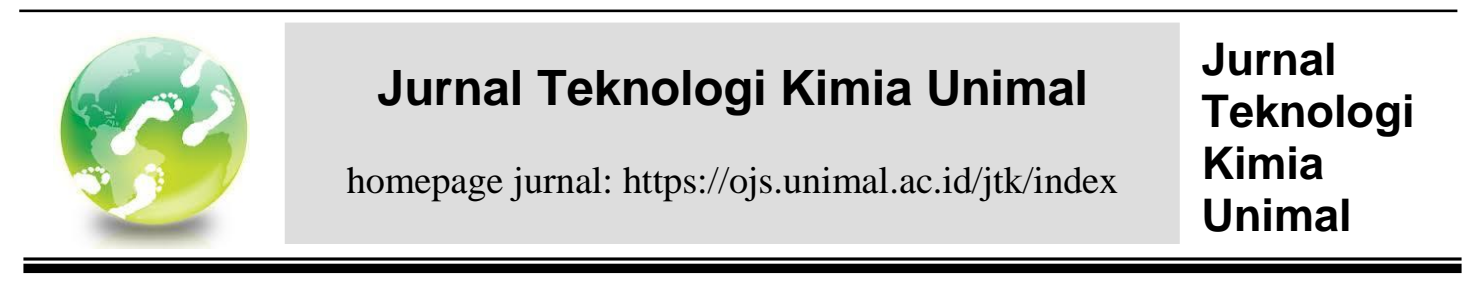

\title{
FORMULASI SEDIAAN GEL MINYAK ATSIRI TANAMAN NILAM (POGOSTEMON CABLIN BENTH) SEBAGAI ANTISEPTIK TANGAN (HAND SANITIZER)
}

\author{
Syamsul Bahri ${ }^{1}$, Zainuddin Ginting ${ }^{1}$, Shella Vanesa ${ }^{1}$, Nasrul ZA ${ }^{1}$ \\ ${ }^{1}$ Program Studi Teknik Kimia, Fakultas Teknik, Universitas Malikussaleh, \\ Kampus Utama Jl. Cot Tengku Nie, Reuleut, Muara Batu, Aceh Utara, \\ Aceh , Indonesia. E-mail: zginting@ unimal.ac.id
}

\begin{abstract}
Abstrak
Indonesia termasuk salah satu negara penghasil minyak atsiri terbesar di dunia, dan minyak ini juga merupakan komoditi yang menghasilkan devisa Negara. Penghasil minyak atsiri yang mempunyai prospek cukup tinggi adalah tanaman nilam (Pogostemon cablin Benth) yang berasal dari provinsi Aceh. Nilam Aceh merupakan nilam terbaik kedua di dunia yang dapat menghasilkan minyak nilam dengan kandungan Patchouli Alcohol (PA) di atas 30\%. Komposisi hand sanitizer yang beredar di pasaran saat ini masih menggunakan alkohol sebagai bahan aktifnya dirasa kurang aman terhadap kesehatan, karena alkohol dapat melarutkan lapisan lemak pada kulit yang berfungsi sebagai pelindung terhadap infeksi mikroorganisme. Pada pemakaian berulang dapat menyebabkan kekeringan serta iritasi pada kulit, oleh sebab itu perlu diteliti bahan lain yang dapat dimanfaatkan sebagai antibakteri. Salah satu bahan alami yang dapat diharapkan sebagai alternatif yang cukup potensial untuk mengganti penggunaan alkohol sebagai zat aktif adalah minyak nilam. Penelitian ini bertujuan untuk membuat formulasi serta menguji efektivitas antiseptik tangan dari sediaan gel minyak atsiri tanaman nilam (Pogostemon cablin Benth) dengan 5 variasi volume, yakni 0; 1; 3; 5; dan $7 \mathrm{~mL}$. Pengujian yang dilakukan terhadap kelima formulasi meliputi sifat fisik gel yaitu, pengujian organoleptik, $p H$, daya sebar, viskositas, dan aktivitas bakteri. Formulasi gel hand sanitizer alami yang baik dan aman diperoleh yaitu pada formula A2K1 (minyak nilam $1 \mathrm{~mL}$, karbopol $9401 \mathrm{gr}$, propilen glikol $5 \mathrm{~mL}$, TEA $1 \mathrm{~mL}$, gliserin $10 \mathrm{~mL}$, metil paraben 0,18 gr, aquadest $100 \mathrm{~mL}$ ), karena memiliki bentuk gel yang sesuai dengan gel yang beredar di pasaran yang dapat menghambat pertumbuhan bakteri staphylococcus aureus dengan diameter zona hambat sebesar 6,8 $\mathrm{mm}$, dengan hasil yang homogen, pH sebesar 8,4 mendekati pH kulit, dan daya sebar menunjukkan konsistensi semisolid yang sangat nyaman dalam penggunaan yaitu sekitar $4-8$ $\mathrm{cm}$.
\end{abstract}

Kata kunci: minyak nilam, gel antiseptik, dan bakteri Staphylococcus aureus 


\section{Pendahuluan}

Indonesia termasuk salah satu negara penghasil minyak atsiri terbesar di dunia, dan minyak ini juga merupakan komoditi yang menghasilkan devisa negara. Oleh karena itu pada tahun-tahun terakhir ini, minyak atsiri mendapat perhatian yang cukup besar dari pemerintah Indonesia. Sampai saat ini Indonesia baru menghasilkan dua belas jenis minyak atsiri yaitu: minyak cengkeh, minyak kenanga, minyak nilam, minyak akar wangi, minyak pala, minyak kayu putih, minyak sereh wangi, minyak jahe, minyak lada, minyak cendana, minyak kemukus, dan minyak masoyi. Penghasil minyak atsiri yang mempunyai prospek cukup tinggi adalah tanaman nilam (Pogostemon cablin Benth) yang berasal dari provinsi Aceh.

Indonesia memiliki tiga jenis tanaman nilam yang dapat dibedakan melalui karakter morfologi, kandungan atau kualitas minyak dan ketahanan terhadap cekaman biotik dan abiotik. Ketiga jenis nilam tersebut adalah Pogostemon cablin Benth (Nilam Aceh), Pogostemon hortensis Packer (Nilam Jawa), dan Pogostemon heyneanus Benth (Nilam Sabun) (Ketaren, 1985).

Diantara ketiga jenis tanaman nilam tersebut yang sering digunakan secara komersial adalah Pogostemon cablin Benth atau sering disebut dengan nama nilam Aceh. Ciri yang mencolok dari nilam Aceh adalah daunnya yang membulat seperti jantung, permukaan bagian bawah yang terdapat bulu-bulu rambut sehingga daun tampak pucat, dan minyak nilam Aceh memiliki kadar patchouli alkohol yang lebih tinggi dari jenis nilam lainnya (Lutony dan Rahmayati, 1994).

Destilasi atau penyulingan adalah suatu metode pemisahan bahan kimia berdasarkan perbedaan kecepatan atau kemudahan menguap (volatilitas) bahan. Secara umum penyulingan adalah pencampuran dua zat cair atau lebih lalu didihkan sehingga menguap dan uap tersebut kemudian didinginkan kembali ke dalam bentuk cairan. Penyulingan minyak nilam adalah suatu proses pengambilan minyak dari bahan kering dengan bantuan air, dimana minyak dan air tidak tercampur. Campuran cairan yang disuling dapat berupa cairan yang tidak larut (immiscible) dan selanjutnya membentuk dua fasa, atau cairan yang saling melarutkan secara sempurna (miscible) yang hanya membentuk satu fasa. Dalam 
pengolahan minyak nilam terdapat tiga metode penyulingan, yaitu penyulingan air (water distillation), penyulingan uap (steam distillation). dan penyulingan air dan uap (water and steam distillation) (Sastrohamidjojo, 2004).

Hand Sanitizer merupakan pembersih tangan yang memiliki kemampuan antibakteri dalam menghambat hingga membunuh bakteri (Retnosari dan Isdiartuti, 2006). Menurut Diana (2012) terdapat dua hand sanitizer yaitu hand sanitizer gel dan hand sanitizer spray. Hand sanitizer gel merupakan pembersih tangan berbentuk gel yang berguna untuk membersihkan atau menghilangkan kuman pada tangan, mengandung bahan aktif alkohol 60\%. Hand sanitizer spray merupakan pembersih tangan berbentuk spray untuk membersihkan atau menghilangkan kuman pada tangan yang mengandung bahan aktif irgasan DP 300 : $0,1 \%$ dan alkohol $60 \%$. Banyak hand sanitizer yang berasal dari bahan alkohol atau etanol yang dicampurkan bersama dengan bahan pengental, misal karbomer, gliserin, dan menjadikannya serupa jelly, gel atau busa untuk mempermudah dalam penggunaannya. Gel ini mulai populer digunakan karena penggunaanya mudah dan praktis tanpa membutuhkan air dan sabun. Gel sanitasi ini menjadi alternatif yang nyaman bagi masyarakat (Hapsari, 2015).

Gel pembersih tangan atau hand sanitizer ini juga dikenal dengan detergen sintentik cair pembersih tangan merupakan sediaan pembersih yang dibuat dari bahan aktif detergen sintetik dengan atau tanpa penambahan zat lain yang tidak menimbulkan iritasi pada kulit (SNI, 1992). Di negara berkembang, detergen sintetik telah menggantikan sabun sebagai bahan kebersihan.

Di Indonesia, syarat mutu detergen sintetik cair pembersih tangan diatur berdasarkan SNI 06-2588- 1992 yang dapat dilihat dalam Tabel 1.1.

Tabel 1. Mutu Hand Sanitizer Berdasarkan SNI 06-2588-1992

\begin{tabular}{|l|l|l|}
\hline No & Jenis Uji & Persyaratan \\
\hline 1 & Kadar zat aktif & Min. $5,0 \%$ \\
2 & $\mathrm{pH}$ & $4,5-8,0$ \\
3 & Emulsi cairan & Stabil \\
4 & Zat tambahan & Sesuai peraturan yang berlaku \\
\hline
\end{tabular}

Sumber : Standar Nasional Indonesia untuk Hand Sanitizer (SNI 06-2588-1992) 


\section{Bahan dan Metode}

Adapun bahan-bahan yang digunakan pada penelitian ini adalah tanaman nilam, air, minyak nilam, karbopol 940, gliserin metil paraben, tritonalamine (TEA), propilen glikol dan aquadest.

Adapun bahan-bahan yang digunakan pada penelitian ini adalah tungku api, ketel uap, ketel bahan, kondensor, bak penampung produk, piknometer, parang, neraca digital, aluminium foil, batang pengaduk, spatula, gelas kimia, pot gel, hot plate, $\mathrm{pH}$ meter universal, kaca arloji, pipet volume, bola penghisap, pipet tetes, lemari pendingin, sarung tangan, viskometer, dan botol plastik.

Tahapan pelaksanaan penelitian dimulai dari bahan baku nilam Aceh dijemur dan disimpan selama 2 hari dan dipotong kecil-kecil. Selanjutnya dimasukkan kedalam ketel bahan sebanyak 25 kg. Siapkan 300 liter air didalam ketel uap lalu panaskan agar menjadi steam. Steam dialirkan kedalam ketel bahan untuk pemanasan nilam selama 4 jam dan menghasilkan minyak nilam. Kemudian minyak nilam di kondensasi untuk merubah fasa menjadi cair. Amati waktu penyulingan, suhu air pendingin dan kandungan minyak pada air kondensat. Kondensat yang dihasilkan dimasukkan kedalam tabung pemisah untuk memisahkan antara air dan minyak nilam. Hasil penyulingan di analisa kandungannya.

Adapun komposisi gel hand sanitizer minyak nilam dapat dilihat pada Tabel 2.1 sebagai berikut:

Tabel 2. Komposisi Gel Hand Sanitizer Minyak Nilam

\begin{tabular}{|c|l|l|}
\hline Simbol & Komposisi & Taraf \\
\hline & & $\mathrm{A}_{1}=$ Minyak nilam $0 \mathrm{~mL}$ \\
& & $\mathrm{~A}_{2}=$ Minyak nilam $1 \mathrm{~mL}$ \\
& & $\mathrm{~A}_{3}=$ Minyak nilam $3 \mathrm{~mL}$ \\
$\mathrm{~A}$ & Bahan aktif & $\mathrm{A}_{4}=$ Minyak nilam $5 \mathrm{~mL}$ \\
& & $\mathrm{~A}_{5}=$ Minyak nilam $7 \mathrm{~mL}$ \\
\hline & & $\mathrm{K}_{1}=$ Karbopol 940 1,0 gr \\
& & $\mathrm{K}_{2}=$ Karbopol 940 1,5 gr \\
$\mathrm{K}$ & Basis gel & $\mathrm{K}_{3}=$ Karbopol 940 2,0 gr \\
& & $\mathrm{K}_{4}=$ Karbopol940 2,5 gr \\
& & $\mathrm{K}_{5}=$ Karbopol 940 3,0 gr \\
\hline
\end{tabular}




\begin{tabular}{|c|c|l|}
\hline B & Zat penstabil & $\mathrm{B}_{1}=$ Propilen glikol $5 \mathrm{~mL}$ \\
\hline C & Pengakali & $\mathrm{C}_{1}=$ TEA $1 \mathrm{~mL}$ \\
\hline D & Pelembab & $\mathrm{D}_{1}=$ Gliserin $10 \mathrm{~mL}$ \\
\hline E & Pengawet & $\mathrm{E}_{1}=$ Metil paraben $0,18 \mathrm{gr}$ \\
\hline F & Pelarut & $\mathrm{F}=$ Aquadest $100 \mathrm{~mL}$ \\
\hline
\end{tabular}

Adapun formulasi yang dihasilkan untuk membuat Gel Hand Sanitizer Minyak Nilam adalah sebagai berikut:

$$
\begin{aligned}
& A_{1} K_{1}-A_{1} K_{2}-A_{1} K_{3}-A_{1} K_{4}-A_{1} K_{5} \\
& A_{2} K_{1}-A_{2} K_{2}-A_{2} K_{3}-A_{2} K_{4}-A_{2} K_{5} \\
& A_{3} K_{1}-A_{3} K_{2}-A_{3} K_{3}-A_{3} K_{4}-A_{3} K_{5} \\
& A_{4} K_{1}-A_{4} K_{2}-A_{4} K_{3}-A_{4} K_{4}-A_{4} K_{5} \\
& A_{5} K_{1}-A_{5} K_{2}-A_{5} K_{3}-A_{5} K_{4}-A_{5} K_{5}
\end{aligned}
$$

Langkah-langkah yang dilakukan pada tahap proses pembuatan gel Hand sanitizer adalah:

Pada formulasi 1, ditimbang karbopol 940 sebanyak 1 gr, kemudian didispersikan dengan $30 \mathrm{ml}$ aquadest panas bersuhu $70^{\circ} \mathrm{C}$ di dalam cawan porselin. Lalu diaduk pada suhu ruangan sampai terbentuk massa gel. Kemudian, ditambahkan Tritonalamine sebanyak $1 \mathrm{~mL}$ ke dalam basis gel lalu diaduk hingga terbentuk massa gel transparan. Ditimbang metil paraben 0,18 gr dan dilarutkan dengan 5 $\mathrm{mL}$ aquadest di dalam gelas kimia $10 \mathrm{~mL}$. Basis gel dipindahkan ke dalam gelas kimia $150 \mathrm{~mL}$, kemudian ditambahkan metil paraben yang telah dilarutkan dan diaduk hingga homogen. Ditambahkan secara perlahan propilen glikol $5 \mathrm{~mL}$; gliserin $10 \mathrm{~mL}$ dan minyak nilam ke dalam basis gel dan diaduk hingga homogen. Setelah semua campuran homogen lalu ditambahkan aquadest sampai volume gel menjadi $100 \mathrm{~mL}$. Kemudian gel dipindahkan ke dalam botol. Lalu disimpan pada tempat yang gelap dan dingin sampai dilakukan pengujian. Selanjutnya, cara di atas diulangi dengan formulasi yang telah ditentukan.

Adapun analisa pada minyak nilam adalah sebagai berikut:

1) Uji Rendemen 
Minyak nilam ditimbang (gram) untuk ditentukan berat rendemennya.

Rendemen $(\%)=\frac{\text { Berat Minyak (gram) }}{\text { Berat Sampel (gram) }}$

2) Pengukuran Berat Jenis

Adapun cara pengukuran berat jenis adalah sebagai berikut:

a. Piknometer kosong ditimbang.

b. Piknometer diisi aquadest lalu ditimbang.

c. Kemudian piknometer kosong diisi dengan minyak nilam dan ditimbang.

Berat Jenis $=\frac{\mathrm{w}_{1}-\mathrm{w} 0}{\mathrm{~W} 2-\mathrm{w}_{0}}$

Keterangan :

$\mathrm{W}_{0}=$ berat piknometer kosong

$\mathrm{W}_{1}=$ berat piknometer + minyak

$\mathrm{W}_{2}=$ berat piknometer + air

Adapun evaluasi sediaan gel adalah sebagai berikut:

1) Pengujian Organoleptik

Pengamatan dilihat secara langsung bentuk, warna dan bau dari gel yang dibuat. Gel biasanya jernih dengan konsistensi setengah padat (Ansel, 1989).

2) Pengujian $\mathrm{pH}$

Penentuan $\mathrm{pH}$ sediaan dilakukan dengan menggunakan stick $\mathrm{pH}$ Universal yang dicelupkan ke dalam sampel gel yang telah diencerkan. Setelah tercelup dengan sempurna, $\mathrm{pH}$ Universal tersebut dilihat perubahan warnanya dan dicocokkan dengan standar $\mathrm{pH}$ Universal. $\mathrm{pH}$ sediaan gel harus sesuai dengan $\mathrm{pH}$ kulit yaitu 4,5-8 (Tranggono et al., 2007).

3) Pengujian Daya Sebar

Sebanyak 0,5 g sampel gel diletakkan di atas kaca arloji, kaca lainnya diletakkan di atasnya dan dibiarkan selama 1 menit. Diameter sebar gel diukur. Setelahnya ditambahkan 150 gr beban tambahan dan didiamkan selama 1 menit lalu diukur diameter yang konstan. Menurut Garg et al. (2002), daya sebar 5-8 cm menunjukkan konsistensi semisolid yang sangat nyaman dalam penggunaan. 
4) Pengukuran Homogenitas

Pengujian homogenitas dilakukan dengan cara sampel gel dioleskan pada sekeping kaca atau bahan transparan lain yang cocok, sediaan harus menunjukkan susunan yang homogen dan tidak terlihat adanya butiran kasar (Anonim, 1985).

5) Uji Aktivitas Antibakteri Bakteri

Uji aktivitas antibakteri ekstrak tanaman nilam terhadap S. aureus dengan metode difusi sumuran, yaitu pada masing-masing media MHA dibuat sumuran yang berdiameter $6 \mathrm{~mm}$ kemudian di isi dengan sediaan gel hand sanitizer ekstrak tanaman nilam dan menggunakan basis gel sebagai kontrol negatif. Media MHA diinkubasi pada suhu $37^{\circ} \mathrm{C}$ selama 24 jam, kemudian diameter zona radikal atau bening yang terbentuk di ukur (Ariani \& Norjannah, 2017).

\section{Hasil dan Diskusi}

\subsection{Pembahasan Penyulingan Minyak Nilam}

Minyak atsiri nilam diperoleh dengan cara penyulingan uap (Steam Distillation). Setelah di suling selama 4 jam, minyak nilam yang dihasilkan berwarna coklat keemasan dengan aroma khas nilam sebanyak $800 \mathrm{~mL}$ dengan berat sampel awal sebanyak $25 \mathrm{~kg}$. Rendemen yang dihasilkan sebesar 3,2\% dan berat jenis yang dihasilkan sebesar 0,904 gr dengan Patchouli Alcohol (PA) sebesar $32,49 \%$.

\subsection{Pembahasan Penelitian Pembuatan Hand Sanitizer Alami Sanitizer Alami}

\section{Analisa Organoleptik Gel Hand Sanitizer Alami Minyak Nilam}

Analisa organoleptik ini dilakukan dengan cara melihat langsung perubahan yang ada pada gel hand sanitizer seperti perubahan bentuk, warna dan aroma. Hasil analisa organoleptik dari formula nomor 1 sampai dengan formula nomor 25 memiliki perbedaan baik itu bentuk, warna dan aroma.

- Bentuk

Pada formula $\mathrm{A}_{1} \mathrm{~K}_{1}, \mathrm{~A}_{2} \mathrm{~K}_{1}, \mathrm{~A}_{3} \mathrm{~K}_{1}, \mathrm{~A}_{4} \mathrm{~K}_{1}$ dan $\mathrm{A}_{5} \mathrm{~K}_{1}$ dengan konsentrasi karbopol sebanyak 1 gr dihasilkan bentuk gel seperti gel pada umumnya yang beredar di pasaran. Sedangkan pada formula $A_{1} K_{2}, A_{1} K_{3}, A_{1} K_{4}, A_{1} K_{5}, A_{2} K_{2}$, 
$\mathrm{A}_{2} \mathrm{~K}_{3}, \mathrm{~A}_{2} \mathrm{~K}_{4}, \mathrm{~A}_{2} \mathrm{~K}_{5}, \mathrm{~A}_{3} \mathrm{~K}_{2}, \mathrm{~A}_{3} \mathrm{~K}_{3}, \mathrm{~A}_{3} \mathrm{~K}_{4}, \mathrm{~A}_{3} \mathrm{~K}_{5}, \mathrm{~A}_{4} \mathrm{~K}_{2}, \mathrm{~A}_{4} \mathrm{~K}_{3}, \mathrm{~A}_{4} \mathrm{~K}_{4}, \mathrm{~A}_{4} \mathrm{~K}_{5}, \mathrm{~A}_{5} \mathrm{~K}_{2}$, $\mathrm{A}_{5} \mathrm{~K}_{3}, \mathrm{~A}_{5} \mathrm{~K}_{4}$ dan $\mathrm{A}_{5} \mathrm{~K}_{5}$ dengan konsentrasi 1,5 gr untuk $\mathrm{K}_{2}, 2$ gr untuk $\mathrm{K}_{3}, 2,5$ gr untuk $\mathrm{K}_{4}$, dan 3 gr untuk $\mathrm{K}_{5}$ menghasilkan gel yang sangat kental dan tidak sesuai dengan gel yang berada di pasaran. Hal ini dikarenakan semakin tinggi konsentrasi karbopol yang di gunakan maka semakin kental pula gel yang dihasilkan. Karbopol sendiri berfungsi sebagai bahan pembawa gel.

\section{- Warna}

Pada formula $A_{1} K_{1}, A_{1} K_{2}, A_{1} K_{3}, A_{1} K_{4}$ dan $A_{1} K_{5}$ menghasilkan warna bening. Hal ini dikarenakan tidak adanya penambahan minyak nilam. Sedangkan pada formula $A_{2} K_{1}, A_{2} K_{2}, A_{2} K_{3}, A_{2} K_{4}, A_{2} K_{5}, A_{3} K_{1}, A_{3} K_{2}, A_{3} K_{3}, A_{3} K_{4}, A_{3} K_{5}$, $\mathrm{A}_{4} \mathrm{~K}_{1}, \mathrm{~A}_{4} \mathrm{~K}_{2}, \mathrm{~A}_{4} \mathrm{~K}_{3}, \mathrm{~A}_{4} \mathrm{~K}_{4}, \mathrm{~A}_{4} \mathrm{~K}_{5}, \mathrm{~A}_{5} \mathrm{~K}_{1}, \mathrm{~A}_{5} \mathrm{~K}_{2}, \mathrm{~A}_{5} \mathrm{~K}_{3}, \mathrm{~A}_{5} \mathrm{~K}_{4}$ dan $\mathrm{A}_{5} \mathrm{~K}_{5}$ berwarna kuning pucat sampai dengan orange. Hal ini dikarenakan adanya penambahan minyak nilam yang berwarna coklat keemasan. Semakin tinggi konsentrasi yang ditambahkan kedalam gel, maka semakin pekat pula warna gel yang dihasilkan. Penambahan minyak nilam berfungsi sebagai bahan aktif pengganti alkohol.

- Aroma

Pada formula $A_{1} K_{1}, A_{1} K_{2}, A_{1} K_{3}, A_{1} K_{4}$ dan $A_{1} K_{5}$ menghasilkan aroma khas gliserin. Hal ini dikarenakan tidak adanya penambahan minyak nilam. Sedangkan pada formula $\mathrm{A}_{2} \mathrm{~K}_{1}, \mathrm{~A}_{2} \mathrm{~K}_{2}, \mathrm{~A}_{2} \mathrm{~K}_{3}, \mathrm{~A}_{2} \mathrm{~K}_{4}, \mathrm{~A}_{2} \mathrm{~K}_{5}, \mathrm{~A}_{3} \mathrm{~K}_{1}, \mathrm{~A}_{3} \mathrm{~K}_{2}, \mathrm{~A}_{3} \mathrm{~K}_{3}$, $\mathrm{A}_{3} \mathrm{~K}_{4}, \mathrm{~A}_{3} \mathrm{~K}_{5}, \mathrm{~A}_{4} \mathrm{~K}_{1}, \mathrm{~A}_{4} \mathrm{~K}_{2}, \mathrm{~A}_{4} \mathrm{~K}_{3}, \mathrm{~A}_{4} \mathrm{~K}_{4}, \mathrm{~A}_{4} \mathrm{~K}_{5}, \mathrm{~A}_{5} \mathrm{~K}_{1}, \mathrm{~A}_{5} \mathrm{~K}_{2}, \mathrm{~A}_{5} \mathrm{~K}_{3}, \mathrm{~A}_{5} \mathrm{~K}_{4}$ dan $\mathrm{A}_{5} \mathrm{~K}_{5}$ beraroma khas nilam. Hal ini dikarenakan adanya penambahan minyak nilam yang aromanya menyengat. Semakin tinggi konsentrasi minyak nilam yang ditambahkan kedalam gel, maka semakin menyengat pula aroma khas nilam yang dihasilkan.

\section{Analisa pH Gel Hand Sanitizer Alami Minyak Nilam}

Analisa $\mathrm{pH}$ ini dilakukan dengan cara menganalisa langsung dengan menggunakan alat $\mathrm{pH}$ meter. Hasil $\mathrm{pH}$ yang didapatkan adalah $8,1-8,8$ dan tidak terlalu sesuai dengan $\mathrm{pH}$ kulit yaitu $4,5-8$, tetapi masih tetap aman digunakan karena hand sanitizer yang dihasilkan terbuat dari bahan alami. 


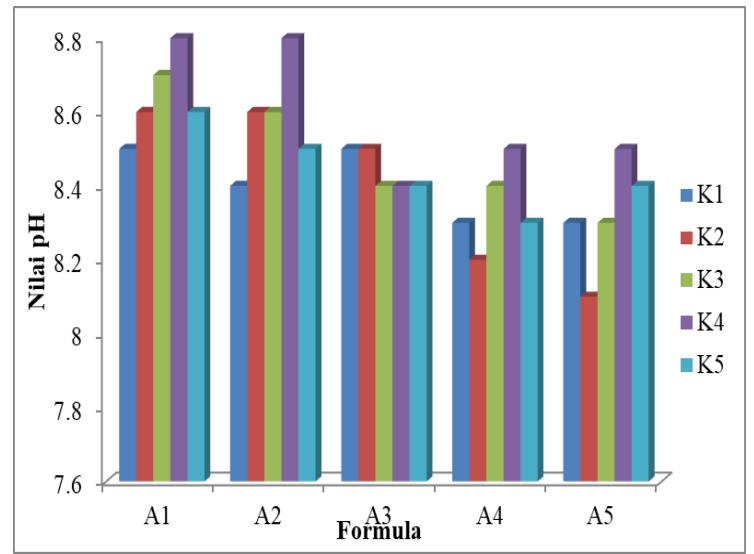

Gambar 1. Hasil Analisa pH Hand Sanitizer Alami

Hal ini dikarenakan, banyaknya penambahan Tritonalamine (TEA) pada saat pembuatan hand sanitizer. Tritonalamine (TEA) berfungsi sebagai agen pembasa dan agen pengemulsi. Pada saat pembuatan hand sanitizer TEA yang digunakan terlalu banyak yaitu sekitar $1 \mathrm{~mL}$, seharusnya TEA yang digunakan sebanyak $1-3$ tetes. Hal ini menyebabkan hand sanitizer yang dihasilkan memiliki pH yang basa dan tidak terlalu sesuai dengan $\mathrm{pH}$ kulit.

\section{Analisa Daya Sebar Gel Hand Sanitizer Alami Minyak Nilam}

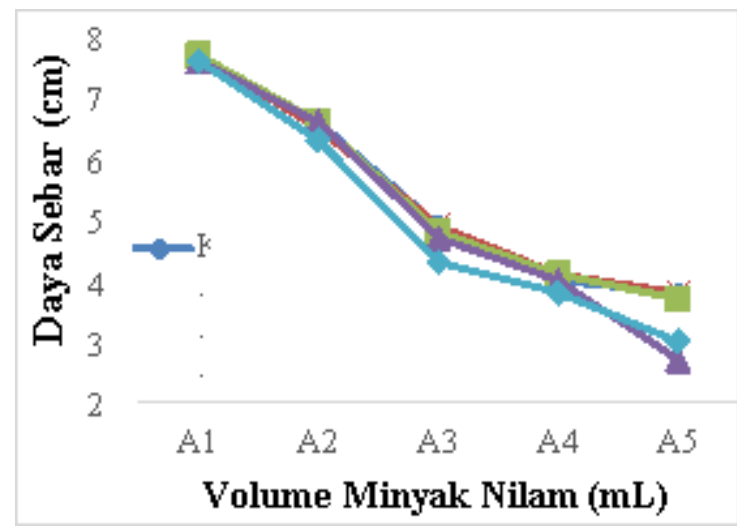

Gambar 2. Hasil Analisa Daya Sebar Hand Sanitizer Alami

Hasil analisa yang dilakukan, menunjukkan bahwa peningkatan luas area sebar disertai dengan adanya penambahan beban yang diberikan, dan hasil yang paling baik terdapat pada formula $\mathrm{A}_{1} \mathrm{~K}_{1}, \mathrm{~A}_{2} \mathrm{~K}_{1}, \mathrm{~A}_{3} \mathrm{~K}_{1}, \mathrm{~A}_{4} \mathrm{~K}_{1}$ dan $\mathrm{A}_{5} \mathrm{~K}_{1}$ karena memiliki nilai daya sebar yang masuk dalam skala daya sebar yang baik. Sediaan 
semisolid yang nyaman digunakan memiliki daya sebar 5 sampai dengan $7 \mathrm{~cm}$ (Garg, A, et al., 2002).

Daya sebar yang baik menyebabkan kontak antara obat dengan kulit berlangsung cepat. Kenaikan dan penurunan daya sebar sangat dipengaruhi oleh konsistensi gel tersebut, dimana hal ini berhubungan dengan nilai viskositas sediaan. Apabila nilai viskositas sediaan tinggi maka luas daya sebar yang dihasilkan rendah, dan sebaliknya. Hal tersebut terjadi karena viskositas yang tinggi menyebabkan gel sulit mengalir sehingga luas area sebar yang dihasilkan kecil (Arista, et al., 2013).

Dari 25 formula dapat dilihat bahwa adanya perbedaan konsentrasi karbopol 940 sebagai gelling agent memberikan pengaruh terhadap penurunan daya sebar sediaan gel hand sanitizer antar formula, dimana semakin tinggi konsentrasi karbopol maka daya sebarnya akan semakin turun. Hal ini serupa dengan penelitian dari (Supomo, et al., 2015) yang menyebutkan bahwa daya sebar yang kecil disebabkan karena adanya peningkatan konsentrasi gelling agent karbopol.

\section{Analisa Homogenitas Gel Hand Sanitizer Alami Minyak Nilam}

Homogenitas merupakan pengujian suatu produk untuk mengetahui kehomogenan suatu sediaan gel hand sanitizer tercampur dengan baik dan tidak mengandung butiran-butiran kasar atau partikel yang terdapat dalam sediaan tersebut larut dengan sempurna (Sorbareeyah, 2015).

Uji homogenitas ini dilakukan dengan tujuan untuk mengetahui homogenitas gel hand sanitizer minyak nilam dengan melihat keseragaman partikel dalam sediaan tersebut. Hasil analisa homogenitas bahwa pada formula $\mathrm{A}_{1} \mathrm{~K}_{1}, \mathrm{~A}_{1} \mathrm{~K}_{2}, \mathrm{~A}_{2} \mathrm{~K}_{1}, \mathrm{~A}_{2} \mathrm{~K}_{2}, \mathrm{~A}_{3} \mathrm{~K}_{1}, \mathrm{~A}_{3} \mathrm{~K}_{2}, \mathrm{~A}_{4} \mathrm{~K}_{1}, \mathrm{~A}_{4} \mathrm{~K}_{2}, \mathrm{~A}_{5} \mathrm{~K}_{1}$ dan $\mathrm{A}_{5} \mathrm{~K}_{2}$ memiliki susunan yang homogen ditandai dengan tidak ada bagian yang tidak tercampur dengan baik. Sedangkan pada formula $A_{1} K_{3}, A_{1} K_{4}, A_{1} K_{5}, A_{2} K_{3}, A_{2} K_{4}, A_{2} K_{5}$, $\mathrm{A}_{3} \mathrm{~K}_{3}, \mathrm{~A}_{3} \mathrm{~K}_{4}, \mathrm{~A}_{3} \mathrm{~K}_{5}, \mathrm{~A}_{4} \mathrm{~K}_{3}, \mathrm{~A}_{4} \mathrm{~K}_{4}, \mathrm{~A}_{4} \mathrm{~K}_{5}, \mathrm{~A}_{5} \mathrm{~K}_{3}, \mathrm{~A}_{5} \mathrm{~K}_{4}$ dan $\mathrm{A}_{5} \mathrm{~K}_{5}$ memiliki sususan yang tidak homogen ditandai dengan adanya bagian yang tidak tercampur dengan baik. Hal ini dikarenakan semakin tinggi viskositas suatu gel, maka semakin 
banyak pula bagian gel yang tidak tercampur dengan sempurna karena adanya penggumpalan gel.

5. Analisa Antibakteri pada Gel Hand sanitizer Alami Minyak Nilam
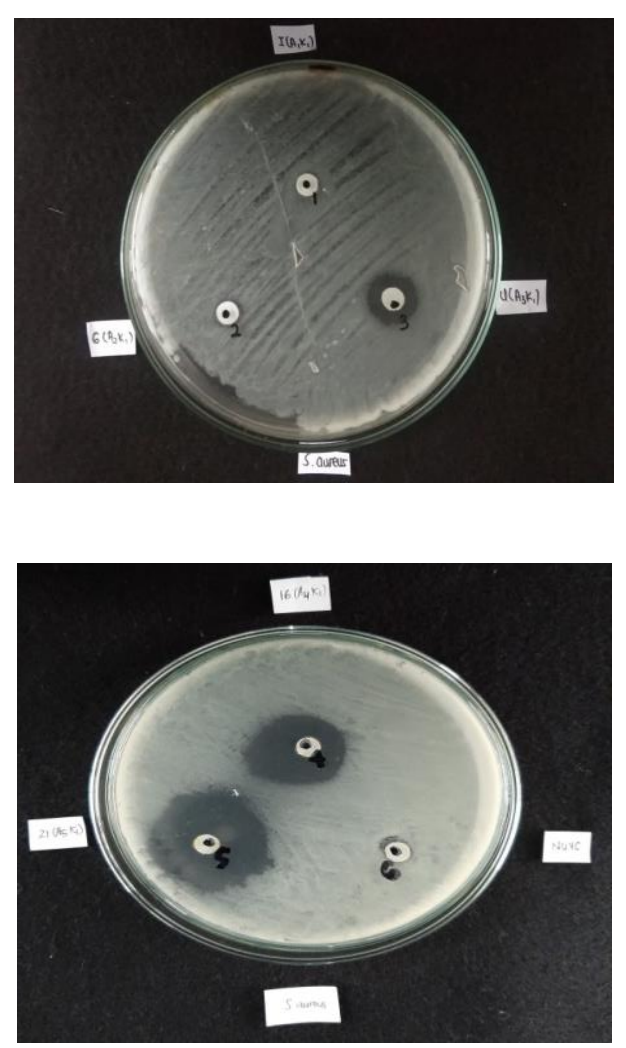

Gambar 3. Analisa Aktivitas Antibakteri Hand sanitizer Alami

Pada penelitian ini minyak nilam digunakan sebagai bahan utama yang berfungsi sebagai antibakteri terhadap Staphylococcus aureus. Pengamatan dan pengukuran dilakukan setelah 1 x 24 jam masa inkubasi. Zona bening merupakan petunjuk kepekaan bakteri terhadap antibiotik atau bahan antibakteri lainnya yang digunakan sebagai bahan uji yang dinyatakan sebagai diemeter zona hambat (Vandepitte et al, 2005).

Ada beberapa formulasi yang di uji aktivitas antibakterinya yaitu formula $\mathrm{A}_{1} \mathrm{~K}_{1}$ tidak ada penambahan minyak nilam diperoleh zona hambat sebesar $0 \mathrm{~mm}$, formula $\mathrm{A}_{2} \mathrm{~K}_{1}$ dengan konsentrasi minyak nilam sebanyak $1 \mathrm{~mL}$ diperoleh zona hambat sebesar $6,8 \mathrm{~mm}$, formula $\mathrm{A}_{3} \mathrm{~K}_{1}$ dengan konsentrasi minyak nilam sebanyak $3 \mathrm{~mL}$ diperoleh daya hambat sebesar $13,9 \mathrm{~mm}$, formula $\mathrm{A}_{4} \mathrm{~K}_{1}$ dengan 
konsentrasi minyak nilam sebanyak $5 \mathrm{~mL}$ diperoleh daya hambat sebesar 20,3 $\mathrm{mm}$, formula $\mathrm{A}_{5} \mathrm{~K}_{1}$ dengan konsentrasi minyak nilam sebanyak $7 \mathrm{~mL}$ diperoleh daya hambat sebesar 29,0 $\mathrm{mm}$ dan hand sanitizer merk Nuvo yang beredar di pasaran diperoleh zona hambat sebesar $6,8 \mathrm{~mm}$. Hal ini menunjukkan semakin banyak konsentrasi minyak nilam, maka semakin besar aktivitas antibakteri seperti yang di nyatakan oleh (Noer, 2011) menyatakan bahwa semakin tinggi konsentrasi menytakan bahwa semakin tinggi konsentrasi suatu bahan maka semakin banyak mikroorganisme yang dapat di hambat sehingga diameter zona hambat juga semakin besar.

\section{Simpulan dan Saran}

Adapun kesimpulan yang diperoleh dari pembahasan hasil penelitian ini ialah sebagai berikut:

1. Hasil analisa penyulingan minyak nilam yang dihasilkan dengan menggunakan metode penyulingan uap (Steam Distilation) adalah rendemen yang dihasilkan sebesar 3,2\% dan berat jenis yang dihasilkan sebesar 0,904 gr dengan Patchouli Alcohol (PA) sebesar 32,49\%.

2. Uji organoleptik sediaan hand sanitizer alami tanpa alkohol dihasilkan produk berbentuk gel, bewarna kuning pucat dan beraroma khas nilam.

3. Formulasi gel hand sanitizer alami yang baik dan aman diperoleh yaitu pada formula $\mathrm{A}_{2} \mathrm{~K}_{1}$ (minyak nilam $1 \mathrm{~mL}$, karbopol $9401 \mathrm{gr}$, propilen glikol $5 \mathrm{~mL}$, TEA $1 \mathrm{~mL}$, gliserin $10 \mathrm{~mL}$, metil paraben 0,18 gr, aquadest $100 \mathrm{~mL}$ ), karena memiliki bentuk gel yang sesuai dengan gel yang beredar di pasaran, homogen, $\mathrm{pH}$ sebesar 8,4 mendekati $\mathrm{pH}$ kulit, dan daya sebar menunjukkan konsistensi semisolid yang sangat nyaman dalam penggunaan yaitu sekitar 4 $-8 \mathrm{~cm}$.

4. Pada pengujian aktivitas antibakteri menggunakan formulasi $\mathrm{A}_{2} \mathrm{~K}_{1}$ gel hand sanitizer alami minak nilam dapat membunuh aktivitas bakteri Staphylococcus aureus dengan zona hambat sebesar $6,8 \mathrm{~mm}$ yang sama dengan hand sanitizer merk Nuvo yang beredar di pasaran. 
Adapun saran pada peneltian selanjutnya adalah peneliti menggunakan variabel konsentrasi Tritonalamine (TEA) sebanyak 1 - 3 tetes saja agar $\mathrm{pH}$ yang dihasilkan tidak terlalu basa dan sesuai dengan $\mathrm{pH}$ kulit.

\section{Daftar Pustaka}

1. Ansel, H. C. 1989. Pengantar Bentuk Sediaan Farmasi. Cetakan I. UI Press. Jakarta.

2. Ariani, N. dan Norjannah. (2017). Daya Hambat Ekstrak Etanol Kulit Buah Pisang Kepok Mentah (Musa paradisiaca forma typica) Terhadap Pertumbuhan Escherichia coli Secara In Vitro. Jurnal Ilmiah Ibnu Sina, 2(2), 296-303.

3. Diana, A. (2012). Pengaruh Desiminasi Dokter Kecil Tentang Penggunaan Hand Sanitizer Gel dan Spray Terhadap Penurunan Angka Kuman Tangan Siswa SDN Demakijo Gamping Sleman. Skripsi. Poltekkes Kemenkes Yogyakarta.

4. Garg, A., Aggarwal, D., Garg, S. dan Sigla, A,K. (2002). Spreading of Semisolid Formulation : An Update. Journal Pharmaceutical Technology, 20(2), 84-102.

5. Hapsari, D. N. (2015). Pemanfaatan Ekstrak Daun Sirih (Piper Betle Linn) Sebagai Hand Sanitizer. Skripsi. Poltekkes Kemenkes Yogyakarta.

6. Ketaren, S. (1985). Pengaruh Teknologi Minyak Atsiri. Jakarta: Balai Pustaka.

7. Lutony, T. L dan Y. Rahmawati. 1994. Produksi dan Perdagangan Minyak Atsiri. Penebar Swadaya, Jakarta.

8. Retnosari, Dewi Isadiartuti, 2006. Studi efektivitas sediaan gel antiseptik tangan ekstrak daun sirih (Piper betle Linn.). Majalah Farmasi Indonesia, 17(4), 163-169

9. Sastrohamidjojo, H. 2004. Kimia Minyak Atsiri. Gajah Mada University Press, Yogyakarta.

10. Sorbareeyah, Lateh M. (2015). formulasi gel tangan sanitizer ekstrak etanol buah asam gelugur (Garciania Atroviridis Griff. Et Andres) sebagai antibakteri terhadap staphylococcus aureus. Surakarta: fakultas farmasi Universitas Muhamadiyah Surakarta.

11. Tranggono, Retno, I., Latifah. dan Fatimah. 2007. Buku Pegangan Ilmu Pengetahuan Kosmestik. PT. Gamedia Pustaka Utama. Jakarta. 